\title{
The effect of rehabilitation at different stages of development of rats marginally malnourished for ten to twelve generations
}

\author{
BY R. J. C. STEWART, HILDA SHEPPARD, \\ R. PREECE AND J. C. WATERLOW \\ Clinical Nutrition and Metabolism Unit, London School of Hygiene \\ and Tropical Medicine, Keppel Street, London $W C_{1} E_{7} H T$
}

(Received 30 July 1979 - Accepted 4 December 1979)

\begin{abstract}
1. Rats which have been maintained for ten to twelve generations on diets of low protein value were rehabilitated in utero (group P), from birth (group F) and from 4 weeks of age (group W).

2. Group $W$ showed little change in physique, behaviour or learning, indicating that for recovery to be effective refeeding must begin earlier.

3. Group $F$ just failed to attain full physical recovery ( $90 \%$ ) whereas group $P$ overgrew by $18.6 \%$ in weight and $8.5 \%$ in length.

4. In a test designed to evaluate learning ability rehabilitated rats of groups $P$ and $F$ were significantly less successful than normal rats, but more successful than rats of group W or rats of the original undernourished colony.

5. Rehabilitation for a further two generations in groups $F$ and $P$ corrected any residual physical and behavioural defects but produced no further improvement on the Lashley (1938) jumping platform.
\end{abstract}

The changes produced in rats by several generations of marginal protein-energy deficiency have been reported earlier (Stewart, 1970; Stewart \& Sheppard, 1971; Stewart et al. 1975). There would appear to be a rapid adaptation in size and shape which stabilizes after two or three generations at a level probably controlled by the severity of the dietary deficiency. The adult males of the deficient colony weighed approximately $40 \%$ less than the well-fed controls, and the females $30 \%$ less. Body lengths were reduced by $\mathrm{I} 2 \%$ and $8 \%$ respectively and this was also the deficit in femur length. Brain weights were reduced by approximately $4.5 \%$. The weight of some organs was very severely reduced (pancreas $42 \%$, kidneys $45 \%$ ) but $23-25 \%$ was the more usual value. Losses in muscle weight must, by difference, have been great. The eyes were an exception, the deficit being negligible $(0.2 \%)$

Alterations were found in the endocrine systems of protein-energy-deficient animals (Platt \& Stewart, 1967; Heard \& Stewart, I97I), exploratory behaviour (Stewart, I97I, 1973), reaction to noise (Stewart, 1971, 1973, 1975a; Stewart et al. 1975) and learning (Turkewitz, 1975).

Many of the changes mimic those found in children born into deprived communities and it is important to know the best developmental periods within which to attempt rehabilitation, the extent of recovery to be expected and, in particular, whether complete recovery can be accomplished within one generation.

Birch (1972) suggested that the small size of the intergenerationally-deprived rats might be the result of a gradual elimination of the larger strains. Preliminary tests indicated that this was unlikely to be the explanation, in that animals cross-fostered at birth attained $90 \%$ (Stewart, 1973) of normal weight and 93\% (Stewart et al. 1973) of normal length, and those recovered in utero might attain greater weights and lengths than animals of the control colony (Stewart, 1976). Body-weights were affected more severely by the deficiencies than bone lengths and it was necessary to determine whether the alterations in length were significant. The work described in this paper is an attempt, with more accurately matched 
groups, to compare and contrast the effects of rehabilitation beginning at weaning, at birth and in utero, on physical growth and to check the earlier finding (Stewart, 1976) that alterations in behaviour and visual perception might persist in generations exhibiting no residual physical defects.

\section{METHODS}

Two diets were used: a low-protein ration net dietary protein energy (NDpE) 0.068 (diet A) and a high-protein ration NDpE 0.1 (diet B). Full details of the proportions and quality of the ingredients as well as the method of compounding into cubes have been described (Payne \& Stewart, 1972).

The methods used in the housing and management of the colonies, post-mortem techniques and methods of recording changes have also been fully described in an earlier report (Stewart et al. 1975).

Animals were weighed at least once per week and five times per week during pregnancy. They were visited and handled regularly. Performance on the Lashley (1938) jumping platform was tested under the conditions described by Turkewitz (1975) and did not involve reward or punishment.

Reactions to unusual noises were difficult to quantify and remain subjective although they are readily recorded in cinematographs. The jangling of a bunch of keys or closing of a metal box (spring-loaded) was used as a stimulus. The deficient animals were always tested in the presence of well-fed rats, and 'recovery rats' were tested in the presence of both deficient and control animals. Thus the differences in response to the same stimulus could be observed.

\section{Experimental procedures}

The experiment began with members of the Ioth generation of the low-protein colony. As far as was possible litter-mate mothers formed the basis of these tests and were matched for age and season of year in which conception occurred. In each of the rehabilitated groups, females were mated with males, usually from the same litter, who had been treated in exactly the same way.

Offspring of the deprived colony could not be separated from the dams before 4 weeks without severe and unacceptable losses. Consequently the animals rehabilitated from weaning were 4 weeks old when first given the high-protein diet (group $W_{1}$; their offspring group $W_{2}$ ).

Other animals born of the colony A mothers were transferred within minutes of birth to well-fed, lactating mothers of colony $B$, were nursed by these mothers and given diet $B$ (high-protein) at weaning (group $F_{1}$; their offspring groups $F_{2}, F_{3}$ etc.).

Some of the mothers of the low-protein colony were given, from the $14^{\text {th }}$ day after mating, the ration of higher protein value. These mothers suckled their own young which, at weaning, were also given diet $B$ (group $P_{1}$; their offspring group $P_{2}$, and the next generation group $P_{3}$ ). All animals of groups $W_{2}, W_{3}, F_{2}, F_{3}, P_{2}$ and $P_{3}$ were nursed by their natural dams and were given only diet $B$ from weaning.

Changes in weight and body size in these three subgroups $\mathrm{W}, \mathrm{F}$ and $\mathrm{P}$ were compared with colony- $B$ rats and matched colony-A rats of generations 10-12. As numbers were small, animals of groups $F_{2}$ and $F_{3}$ and $P_{2}$ and $P_{3}$ were combined for statistical analysis. 
Table I. Weights at 26 weeks of age of rats in the various test groups $\dagger$

$\dot{0}$

\begin{tabular}{|c|c|c|c|c|c|c|c|c|}
\hline \multirow[b]{2}{*}{ Group } & & & & & & & & \\
\hline & $\begin{array}{l}\text { No. } \\
\text { of rats }\end{array}$ & $\begin{array}{c}\text { Mean } \\
\text { wt } \\
(\mathrm{g})\end{array}$ & SEM & $\begin{array}{l}W \mathrm{t} \\
\text { (\%) control } \\
\text { group B) }\end{array}$ & $\begin{array}{l}\text { No. } \\
\text { of rats }\end{array}$ & $\begin{array}{c}\text { Mean } \\
\text { wt } \\
(\mathrm{g})\end{array}$ & SEM & $\begin{array}{c}W t \\
(\% \text { control } \\
\text { group B) }\end{array}$ \\
\hline $\begin{array}{l}\text { B (well-fed } \\
\text { control) }\end{array}$ & 42 & 429 & $6 \cdot 3$ & 100 & 49 & 255 & 5.0 & 100 \\
\hline $\begin{array}{l}\text { A (deficient } \\
\text { control) }\end{array}$ & 42 & 236 & $4 \cdot 3$ & $55 \cdot 0^{* * *}$ & 57 & 170 & $4 \cdot 1$ & $66 \cdot 7^{* *}$ \\
\hline$W_{1}$ & 48 & 279 & 5.9 & $65 \cdot 0^{* * *}$ & 46 & 189 & $4 \cdot 8$ & $74^{\cdot 1^{* *}}$ \\
\hline $\mathrm{w}_{2}$ & 7 & 353 & 130 & $82 \cdot 3^{* * *}$ & 7 & 219 & 14.7 & $85.9^{*}$ \\
\hline $\mathrm{W}_{3}$ & 8 & 393 & 8.7 & $91 \cdot 6^{*}$ & 9 & 245 & $5 \cdot 2$ & $96 \cdot 1$ \\
\hline$F_{1}$ & 18 & 387 & 3.8 & $90 \cdot 2^{* * *}$ & 12 & 232 & $9 \cdot 7$ & $91 \cdot 0^{*}$ \\
\hline$F_{2}$ & 16 & 409 & 7.9 & $95.3^{*}$ & 28 & $24 I$ & $4 \cdot 2$ & 94.5 \\
\hline$F_{8}$ & 18 & 442 & II. 3 & 103.0 & 9 & 264 & $12 \cdot 8$ & 103.5 \\
\hline$P_{1}$ & 18 & 509 & 12.2 & $118.6^{* *}$ & 28 & 299 & $8 \cdot 4$ & 117.3 \\
\hline $\mathbf{P}_{2}$ & 14 & 464 & 23.8 & $108.2^{*}$ & 27 & 275 & $7 \cdot 4$ & 107.8 \\
\hline$P_{3}$ & 16 & 428 & 12.8 & 99.8 & 16 & 257 & $8 \cdot 3$ & $100 \cdot 7$ \\
\hline
\end{tabular}

$\dagger B$, rats given adequate-protein diet net dietary protein energy (NDpE) $O . I$ for ten to twelve generations; $A$, rats given low-protein diet NDpE 0.068 for ten to twelve generations; $W_{1}$, rats of colony $A$ given diet B from weaning (4 weeks); $W_{2}$, offspring of $W_{1} ; W_{3}$, offspring of $W_{2} ; F_{1}$, rats of colony $A$ cross-fostered at birth to dams of colony $B ; F_{2}$, offspring of $F_{1} ; F_{3}$, offspring of $F_{2} ; P_{1}$, offspring of colony-A mothers given diet $B$ in the last third of pregnancy; $P_{2}$, offspring of $P_{1} ; P_{3}$, offspring of $P_{2}$.

\section{RESULTS}

Pregnancy, parturition and 4-week deaths

Group $W_{1}$. Animals in this group were, until weaning, part of colony A and their performance did not differ from that of the rest of the colony.

Group $F_{1}$. Once again, this group did not differ from colony A during pregnancy and parturition. As in the original colony, a few young died during the first day or so of life, but if those isolated instances where the foster mother killed the whole litter are ignored, early deaths were much lower than in colony A.

Group $P_{1}$. The mothers in this group gained more weight during pregnancy than did colony A rats $(76 \mathrm{~g} v .60 \mathrm{~g})$. The young they produced weighed $5.4 \mathrm{~g}$, the same as the newborn produced by the heavier and skeletally-larger females of colony $B$. There were difficulties at parturition and, unfortunately, a few mothers and young were lost because some of the small mothers could not deliver their young without assistance. In other instances the young were damaged and died or had to be killed immediately. The reproductive performance of the rehabilitated dams appeared to be greatly improved if only the weight of individual offspring was considered; but, due to the difficulties of parturition the number of surviving pups at 3-4 d was not significantly greater than the mean for colony $A$. This situation altered quite quickly, for deaths in the next 3 weeks were much lower than amongst colony A rats. However, as implantations were lower (Gupta \& Christie, I 968) and losses at parturition higher than in colony $B$ rats, the number of young reaching maturity from equal groups of mothers was lower than in the well-fed colony $B$. 
Table 2. Body lengths at 26 weeks of age of rats in the various test groups $\dagger$

\begin{tabular}{|c|c|c|c|c|c|c|c|c|}
\hline \multirow[b]{2}{*}{ Group } & \multicolumn{4}{|c|}{ శ" } & \multicolumn{4}{|c|}{ 웅 } \\
\hline & $\begin{array}{l}\text { No. } \\
\text { of rats }\end{array}$ & $\begin{array}{l}\text { Mean } \\
\text { length } \\
(\mathrm{mm})\end{array}$ & SEM & $\begin{array}{c}\text { Length } \\
\text { (\% control } \\
\text { group B) }\end{array}$ & $\begin{array}{l}\text { No. } \\
\text { of rats }\end{array}$ & $\begin{array}{l}\text { Mean } \\
\text { length } \\
(\mathrm{mm})\end{array}$ & SEM & $\begin{array}{l}\text { Length } \\
\text { (\% control } \\
\text { group B) }\end{array}$ \\
\hline $\begin{array}{l}\text { B (well-fed } \\
\text { control) }\end{array}$ & I 6 & $203 \cdot 2$ & I.98 & 100 & 16 & $182 \cdot 9$ & $1 \cdot 25$ & 100 \\
\hline $\begin{array}{l}\text { A (deficient } \\
\text { control) }\end{array}$ & I 6 & $179 \cdot 6$ & $1 \cdot 62$ & $88 \cdot 4^{* * *}$ & 16 & $169 \cdot 3$ & $I \cdot 26$ & $92 \cdot 6^{* * *}$ \\
\hline$W_{1}$ & 12 & 188.7 & I 86 & $92 \cdot 9^{* * *}$ & 13 & 173.0 & $I \cdot 84$ & $94 \cdot 6^{* * *}$ \\
\hline$F_{1}$ & 12 & 200.0 & 1.9 & $98 \cdot 4$ & 14 & $178 \cdot 0$ & $2 \cdot 6$ & $97 \cdot 3$ \\
\hline$F_{2}$ & 8 & 203.63 & $2 \cdot 7$ & $100 \cdot 2$ & 8 & $182 \cdot 75$ & $2 \cdot 4$ & 99.9 \\
\hline$F_{3}$ & 8 & $207 \cdot 25$ & $I \cdot 4$ & 102 & 8 & $184 \cdot 25$ & 2.9 & $100 \cdot 7$ \\
\hline$P_{1}$ & 8 & 220.4 & $1 \cdot 7$ & $108 \cdot 5^{* * *}$ & 11 & $1950^{\circ}$ & 3.5 & $106 \cdot 6^{* * *}$ \\
\hline$P_{2}$ & 10 & $207 \cdot 5$ & $3 \cdot 9$ & 102 & 10 & $183 \cdot 15$ & $3 \cdot 6$ & $100 \cdot 2$ \\
\hline$P_{3}$ & 8 & $202 \cdot 75$ & 4.0 & 99.8 & 10 & $181 \cdot 35$ & $2 \cdot 7$ & $99 \cdot 2$ \\
\hline
\end{tabular}

$* * * P<0.001$.

$+\mathrm{B}$, rats given adequate-protein diet net dietary protein energy (NDpE) 0.1 for ten to twelve generations; $A$, rats given low-protein diet NDpE 0.068 for ten to twelve generations; $W_{1}$, rats of colony $A$ given diet $B$ from weaning (4 weeks); $W_{2}$, offspring of $W_{1} ; W_{3}$, offspring of $W_{2} ; F_{1}$, rats of colony $A$ cross-fostered at birth to dams of colony $B ; F_{2}$, offspring of $F_{1} ; F_{3}$, offspring of $F_{2} ; P_{1}$, offspring of colony-A mothers given diet $B$ in the last third of pregnancy; $P_{2}$, offspring of $P_{1} ; P_{3}$, offspring of $P_{2}$.

\section{Weights}

\section{Body measurements}

The results are summarized in Table $\mathrm{I}$.

Group $W$. In the first generation (group $\mathrm{W}_{1}$ ) weaning of the colony $\mathrm{A}$ animals onto diet B was followed by rapid catch-up growth. At 8 weeks the weight of the young males was more than double that of the colony $A$ rats of the same age, although only half that of the well-fed controls. The catch-up continued, but was not complete, since at 26 weeks the males only weighed $65 \%$ as much as the controls. The females followed a similar pattern.

The offspring (group $\mathrm{W}_{2}$ ) of these under-sized females weighed $5 \cdot 1 \mathrm{~g}$ at birth, compared with birth weights of $4.3 \mathrm{~g}$ for the original colony $\mathrm{A}$ and $5.4 \mathrm{~g}$ for well-fed controls (colony $\mathrm{B}$ ). At 26 weeks their weight was approximately $85 \%$ of that of the controls. Thus 'catch-up' was better than that of their parents, but it was still not complete.

The next generation (group $\mathrm{W}_{3}$ ) was born at normal weight $(5 \cdot 4 \mathrm{~g})$, but again 'catch-up' was not complete especially in the males, although the deficit was small.

Group $F$. In the first generation (group $F_{1}$ ) the birth weight was that of colony A $(4 \cdot 3 \mathrm{~g}$ ). The cross-fostering produced a rate of weight gain which was nearly as rapid as that of the controls. These rats reached only $86 \%$ of the control weight at 2 weeks and $96 \%$ at 8 weeks. Thereafter the rate of growth fell off a little, so that at 26 weeks they weighed only $90 \%$ as much as the controls. The difference is significant in both sexes.

The offspring of these females (group $F_{2}$ ) were born at normal weights $(5.45 \mathrm{~g})$. They grew at first even faster than the controls; the group $F_{2}$ males at I week weighed $7 \%$ more than the controls. This supranormal rate was not maintained; at 26 weeks both male and female weights were $95 \%$ of the controls, a difference which is just significant.

The next generation (group $\mathrm{F}_{3}$ ) showed a similar but more prolonged pattern of overgrowth. Compared with the controls these rats were $10 \%$ overweight at 12 weeks and $3 \%$ overweight at 26 weeks.

Group $P$. The first generation (group $\mathrm{P}_{1}$ ) born of mothers of the deficient colony who had been given a good diet during the last week of pregnancy, were of normal weight at birth. 
Table 3. Femur lengths at $\mathbf{2 6}$ weeks of age of rats in the various test groups $\dagger$

\begin{tabular}{|c|c|c|c|c|c|c|c|c|}
\hline & & & & & & & & \\
\hline Group & $\begin{array}{l}\text { No. } \\
\text { of rats }\end{array}$ & $\begin{array}{l}\text { Mean } \\
\text { length } \\
(\mathrm{mm})\end{array}$ & SEM & $\begin{array}{l}\text { Length, } \\
\text { (\% control } \\
\text { group B) }\end{array}$ & $\begin{array}{l}\text { No. } \\
\text { of rats }\end{array}$ & $\begin{array}{c}\text { Mean } \\
\text { length } \\
(\mathrm{mm})\end{array}$ & SEM & $\begin{array}{l}\text { Length, } \\
\text { (\% control } \\
\text { group B) }\end{array}$ \\
\hline $\begin{array}{c}\text { B (well-fed } \\
\text { control) }\end{array}$ & 16 & $38 \cdot 9$ & 0.22 & 100 & 16 & $33^{\circ} 9$ & 0.13 & 100 \\
\hline $\begin{array}{l}\text { A (deficient } \\
\text { control) }\end{array}$ & 16 & $34 \cdot 2$ & $0 \cdot 38$ & $87 \cdot 9^{* * *}$ & 16 & $31 \cdot 4$ & 0.21 & $92 \cdot 6^{* * *}$ \\
\hline$W_{1}$ & 12 & 35.9 & 0.3 & $92 \cdot 3^{* * *}$ & 12 & $32 \cdot 36$ & 0.34 & $95^{\circ} 5^{* * *}$ \\
\hline$F_{1}$ & 12 & $38 \cdot 2$ & $0 \cdot 29$ & $98 \cdot 2$ & I4 & $33 \cdot 5$ & 0.19 & $98 \cdot 8$ \\
\hline$F_{2}$ & 8 & $38 \cdot 4$ & 0.42 & 98.7 & 8 & $34^{-1}$ & 0.32 & IOI \\
\hline $\mathrm{F}_{\mathbf{8}}$ & 8 & $39 \cdot 3$ & 0.28 & $101 \cdot 0$ & 8 & 33.94 & $0.4 I$ & 100 \\
\hline$P_{1}$ & 8 & $41 \cdot 2$ & 0.65 & $105.9^{* * *}$ & 11 & $34 \cdot 77$ & 0.26 & $102 \cdot 6^{* *}$ \\
\hline $\mathbf{P}_{2}$ & 10 & 39.05 & 0.46 & $100 \cdot 0$ & 10 & $33 \cdot 75$ & 0.34 & $99 \cdot 6$ \\
\hline$P_{3}$ & 8 & $38 \cdot 3$ & $0.6 I$ & $98 \cdot 5$ & 10 & $34 \cdot 0$ & 0.36 & $100 \cdot 3$ \\
\hline
\end{tabular}

** $0.01>P>0.001, * * * P<0.001$.

$\dagger \mathrm{B}$, rats given adequate-protein diet net dietary protein energy (NDpE) 0.1 for ten to twelve generations; $A$, rats given low-protein diet NDpE 0.068 for ten to twelve generations; $W_{1}$, rats of colony $A$ given diet $B$ from weaning ( 4 weeks); $W_{2}$, offspring of $W_{1} ; W_{3}$ offspring of $W_{2} ; F_{1}$, rats of colony $A$ cross-fostered at birth to dams of colony $B ; F_{2}$, offspring of $F_{1} ; F_{3}$, offspring of $F_{2} ; P_{1}$, offspring of colony-A mothers given diet $B$ in the last third of pregnancy; $P_{2}$, offspring of $P_{1} ; P_{3}$, offspring of $P_{2}$.

They grew significantly faster than the controls; by I 2 weeks the males were $18.5 \%$ heavier and the females $15.5 \%$ heavier than the colony-B rats. This difference was maintained at 26 weeks.

These overweight females produced young (group $\mathrm{P}_{2}$ ) weighing $5.5 \mathrm{~g}$ at birth, slightly more than the average of colony $B$. Again these rats grew faster than the controls, but not to the same extent as their parents. At 26 weeks both males and females were $8 \%$ above the mean control weights.

The third generation (group $\mathrm{P}_{3}$ ) were of normal weight at birth. At 12 weeks they were slightly heavier than the controls, but this overweight was not maintained and at 26 weeks the weights of both sexes were the same as those of the controls.

\section{Body, head and femur lengths (Tables 2-4)}

Group $W$. Although in the group $\mathrm{W}_{1}$ males body, head and femur lengths were all greater than those found in rats of colony $A$, they remained at less than $93 \%$ of the control values. Recovery was slightly greater in the females, reaching between 94 and $96 \%$.

There was very little change in the next generation, and as from their weights the rats did not appear to recover before the third generation, body measurements were discontinued.

Group $F$. When the animals of colony A were fostered to well-fed lactating dams the changes were marked. Body length in the males increased from $180 \mathrm{~mm}$ found in the deficient rats to $200 \mathrm{~mm}$ ( $98 \%$ of the well-fed controls), and in the females from 169 to $178 \mathrm{~mm}$ $(97.3 \%$ of the controls). Head and femur lengths were also near normal. In the next two generations the mean measurements (males and females) were within $2 \%$ of those found in the well-fed colony.

Group P. Re-feeding of the pregnant females of the deficient colony led, in their male offspring, to an overgrowth in body length, head length and femur length. Changes in the females were less marked. These increases were seen only in the original generation. The average values in groups $P_{2}$ and $P_{3}$ were within $2 \%$ of those found in the well-fed colony. 
Table 4. Head lengths at 26 weeks of age of rats in the various test groups $\dagger$

\begin{tabular}{|c|c|c|c|c|c|c|c|c|}
\hline \multirow[b]{2}{*}{ Group } & & \multicolumn{4}{|c|}{$q$} \\
\hline & $\begin{array}{l}\text { No. } \\
\text { of rats }\end{array}$ & $\begin{array}{l}\text { Mean } \\
\text { length } \\
(\mathrm{mm})\end{array}$ & SEM & $\begin{array}{l}\text { Length, } \\
\text { (\% control } \\
\text { group B) }\end{array}$ & $\begin{array}{l}\text { No. } \\
\text { of rats }\end{array}$ & $\begin{array}{l}\text { Mean } \\
\text { length } \\
(\mathrm{mm})\end{array}$ & SEM & $\begin{array}{l}\text { Length, } \\
\text { ( } \% \text { control } \\
\text { group B) }\end{array}$ \\
\hline $\begin{array}{l}\text { B (well-fed } \\
\text { control) }\end{array}$ & 16 & $52 \cdot 6$ & 0.29 & 100 & I6 & $48 \cdot 6$ & 0.33 & 100 \\
\hline $\begin{array}{l}\text { A (deficient } \\
\text { control) }\end{array}$ & 16 & 46.8 & $0.4 \mathrm{I}$ & $88 \cdot 97^{* * *}$ & 16 & 44.7 & 0.32 & $92 \cdot 0^{* * *}$ \\
\hline $\mathrm{w}_{2}$ & 12 & $48 \cdot 8$ & 0.28 & $92 \cdot 7^{* * *}$ & 13 & $45 \cdot 7$ & 0.64 & $94 \cdot 0^{* * *}$ \\
\hline$F_{1}$ & 12 & $52 \cdot 3$ & 0.48 & $99 \cdot 4$ & 14 & $47 \cdot 5$ & 0.31 & $97 \cdot 7^{*}$ \\
\hline$F_{2}$ & 8 & 52.25 & 0.41 & $99 \cdot 4$ & 8 & $47 \cdot 75$ & 0.53 & $97 \cdot 7$ \\
\hline$F_{3}$ & 8 & $52 \cdot 56$ & 0.62 & 99.8 & 8 & 48.68 & 0.54 & 100 \\
\hline$P_{1}$ & 8 & 54.1 & 0.77 & $102.8 *$ & II & $49 \cdot 45$ & 0.71 & $101 \cdot 9$ \\
\hline$P_{2}$ & 10 & 52.6 & 0.54 & 100 & 8 & 48.15 & 0.49 & $99 \cdot 1$ \\
\hline$P_{3}$ & 8 & $51 \cdot 56$ & 0.79 & $98 \cdot I$ & 8 & $48 \cdot 55$ & 0.56 & 99.8 \\
\hline
\end{tabular}

$\dagger \mathrm{B}$, rats given adequate-protein diet net dietary protein energy (NDpE) 0.1 for ten to twelve generations; $A$, rats given low-protein diet NDpE 0.068 for ten to twelve generations; $W_{l}$, rats of colony $A$ given diet $B$ from weaning (4 weeks); $W_{2}$, offspring of $W_{2} ; W_{3}$, offspring of $W_{2} ; F_{1}$, rats of colony $A$ cross-fostered at birth to dams of colony $B ; F_{2}$, offspring of $F_{1} ; F_{3}$, offspring of $F_{2} ; P_{1}$, offspring of colony-A mothers given diet $B$ in the last third of pregnancy; $\mathbf{P}_{2}$, offspring of $\mathbf{P}_{1} ; \mathbf{P}_{3}$, offspring of $\mathbf{P}_{2}$.

\section{Susceptibility to noise}

Group-B animals when exposed to an unusual noise might jump or jerk in response to the first stimulus. They would then investigate the cause and, unless the noise was loud, ignore repetitions and continue with their feeding or grooming. In contrast, group-A animals jumped violently, often all four feet would leave the floor at one time, and this violent reaction would occur as often as the stimulus was repeated.

Group $W$. Animals of group $\mathrm{W}_{1}$ were indistinguishable from rats of colony $\mathrm{A}$, and although some recovery occurred in group $\mathrm{W}_{2}$, only in group $\mathrm{W}_{3}$ could they be regarded as approaching normal.

Group $F$. The fostered animals showed a marked improvement compared with those of colony-A, but were rather more reactive than colony-B rats. Animals of groups $F_{2}$ and $F_{3}$ showed no residual effects.

Group $P$. These animals reacted to unusual noises in a similar manner, or even more strongly, than the original colony A rats. Certainly they reacted more violently than did group $F_{1}$. Observers were not sure whether or not some excess reaction could be discerned in group $P_{2}$. There was certainly no residual effect in group $P_{3}$.

\section{Lashley platform}

Colony-B rats could be seen to be examining the doors. They then made a choice, jumped and, if wrong, re-examined the doors and made another choice without any signs of distress. Twenty members of the colony-B group were tested and each reached the set criteria in all three tests. The average number of trials (total for three tests) to attain this standard was 170 (Fig. I). In contrast, the deficient animals of colony A showed less interest in the.doors and, having made a wrong choice, would often continue to jump for the wrong door. After a series of failures they would try to climb down from or jump off the platform, might crawl backwards and fall off and, in extreme instances, squeal and become very disturbed. Many of the colony-A animals failed to reach the set criteria. Two failed on the first test and of the eighteen presented with the second test one failed and a further four failed the last test. Therefore only $65 \%$ of the deficient colony successfully negotiated the three tests. These 


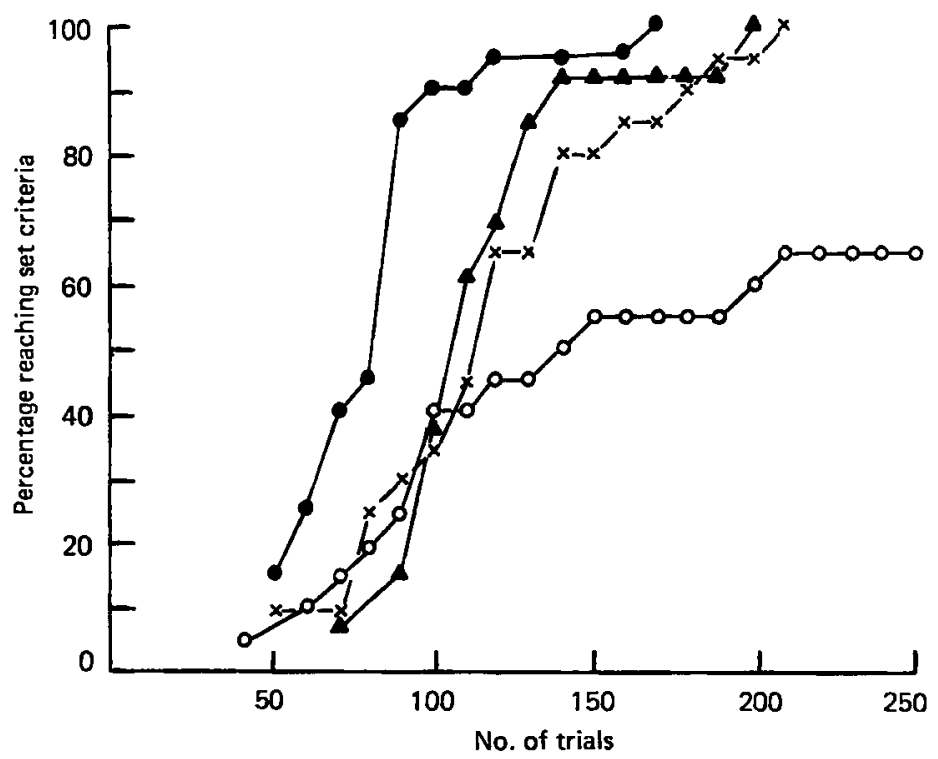

Fig. I. Cumulative percentage of rats passing all three tests with the Lashley (1938) jumping platform (for details, see p. 404 and 408 ) in relation to the total number of trials required. $\mathrm{O}-\mathrm{O}$, Colony $\mathrm{A}$, marginally-malnourished for ten to twelve generations; $\mathbf{\Delta}-\mathbf{\Lambda}$, group $\mathbf{F}_{1}$, offspring of colony $\mathbf{A}$ mothers cross-fostered at birth to normal mothers; $x-x$, group $\mathbf{P}_{1}$, offspring of colony $A$ mothers given normal diet during last third of pregnancy; - colony $\mathrm{B}$, controls given normal diet throughout.

required an average of 230 trials $v$. 170 required by colony-B rats (Fig. I). The four rats which negotiated tests $I$ and 2 but failed on test 3 averaged 259 trials before they were regarded as non-passers.

Group $W_{1}$. These animals were certainly no more successful than those of colony $\mathrm{A}$ and might have been slightly less so. Of the animals $71 \%$ accomplished the three tests, requiring an average of 230 trials. Their behaviour in test situations was indistinguishable from that of colony A rats. The second generation (group $\mathrm{W}_{2}$ ) was not tested.

Group $F$. All the animals of group $\mathrm{F}_{1}$ reached the set criteria but required extra trials, I 90 v. I 70 required by the rats of colony B (Fig. I). A few of these animals showed the disturbed reactions seen in rats of colony $A$, but most would have been accepted as 'colony-B-style' rats. In the second and third generations (combined) the average number of trials needed to reach the criteria was still over 200 , but none of the animals exhibited any of the disturbed reactions associated with groups $A$ and $W_{1}$.

Group $P$. All animals of group $\mathrm{P}_{1}$ also reached the set criteria (Fig. 1) but, as for the fostered group, needed extra trials, 2 Io $v$. I 70 trials required for rats of the well-fed colony. One or two animals reacted badly to the test situation but in no instance was the reaction as severe as in colony- $A$ rats. The second and third generations (combined) all reached the set criteria in an average of 220 trials, but did not show any signs of the reactions which were so prominent a feature in groups $\mathrm{A}$ and $\mathrm{W}_{1}$.

The statistical significance of these results was examined by the Kolmogorov-Smirnov two-sample test. They fall into three significantly different categories $(P<0.05)$. The best performance was that of the control group $B$. Next came the rehabilitated groups $P_{1}$, $P_{2+3}, F_{1}$ and $F_{2+3}$, which were not significantly different from each other. Finally, groups $A$ and $W_{1}$ performed equally badly, and were significantly 'worse' than those of the preceding category. 


\section{DISCUSSION}

From the report of McCance \& Widdowson (1962) it was anticipated that re-feeding from the fourth week of age would have comparatively little effect on weight and length. It proved also to have little, if any, effect on susceptibility to noise or performance on the Lashley (1938) jumping platform.

Great improvements in the weight and length attained at 6 months of age were brought about by adequate feeding from birth, but this was surpassed when the rehabilitation was initiated in utcro. Whereas those re-fed from birth just failed to attain normal size, those whose mothers were re-fed grew to be larger and heavier than the control rats.

The in utero recovery was started when, in a normal pregnancy, the growth spurt is about to begin. Endocrine glands and their secretions are altered by malnutrition (Platt \& Stewart 1962, I967: Heard \& Stewart, 1971) and it is likely that correcting the food deficiencies when growth is becoming dominant (the last third of gestation) has led to an overgrowth. The thyroid gland is known to be depressed by malnutrition (Platt \& Stewart, 1962) and giving small (physiological) doses of thyroxine to a malnourished pregnant rat leads to the birth of full-sized young (Soerjodibroto et al. 1974). Over the next two generations the overgrowth observed in group $\mathrm{P}_{1}$ gradually disappeared and the animals became indistinguishable from those of the control colony. Although not significant, there was a tendency for the offspring of those re-fed from birth to increase in length and weight, so that those whose grandparents were cross-fostered tended to be slightly oversize.

Thus the original suggestion of Birch (1972) that maintaining rats on diets of low protein value for twelve generations may have led to an involuntary selection of the smaller strains, proved to be untenable. In contrast, the results support the suggestion (Stewart, $1975 b$ ) that the interplay of endocrine glands is an important factor in protein-energy deficiency.

The behaviour of all the rats rehabilitated in utero or from birth was more like that of animals in colony $B$ than that of rats in the deficient colony. Surprisingly, animals which were rehabilitated in utero and grew to a size greater than normal exhibited more of the behavioural signs associated with the deficient colony than did those re-fed from birth. It is likely, from the reports of Frankova (1974), that the aberrant behaviour is 'learned' from the deficient mothers before weaning, whereas those cross-fostered at birth were reared by normal mothers.

The Lashley (1938) jumping platform has many critics. However, in the present work every effort was made to ensure that the conditions were constant, and the results are used mainly to indicate that the deficient, control and recovery groups were different. It had been expected that animals of groups $\mathrm{F}_{2+3}$ and $\mathrm{P}_{2+3}$ would have been similar, if not identical to those of colony $\mathrm{B}$. The finding that they were significantly different and could not be differentiated from groups $P_{1}$ and $F_{1}$ indicates the need for longer, and perhaps more selective, tests on 'recovered' animals.

The results reported indicate that: $(a)$ it is possible to obtain full physical recovery after ten to twelve generations of malnutrition, but that this may require more than one generation of refeeding; $(b)$ maternal behaviour has a very important effect on the later behaviour of the offspring; (c) some residual effects in 'learning' and behaviour may continue when physical recovery would appear to be complete. A 'learning' defect can probably be eliminated by extending the training period.

It is natural to ask whether these findings in the rat have any relation to human situations. Stewart $(1975 a)$ has pointed out the correspondence between the low birth weight, high perinatal mortality and reduction in final body size in the rat colony $\mathrm{A}$ and the characteristics of human populations which have been marginally malnourished for generations.

Children who are born small-for-gestational-age (SGA) tend to remain small, at least up 
to the age of 3 years, even in countries where there is presumably no limitation on their food supply (Cruise, 1973; Falkner, 1978). The SGA infant, well-fed from birth, would be equivalent to the pups of colony A who were cross-fostered by normal mothers. According to the hypothesis of Dobbing (1974) permanent stunting only occurs when restrictions are applied during the brain growth spurt. As this occurs earlier in relation to birth in man than in the rat, one might expect good nutrition during the suckling period to be less effective in restoring normal growth in man than in the rat. However, it is hardly possible to make quantitative comparisons between two such different species.

It is difficult to draw any conclusions from observations in developing countries. Low birth weights are very common, and postnatal growth is generally unsatisfactory, at least between approximately 3 months and 3 years (e.g. Waterlow \& Rutishauser, 1974). However, we are faced with the problem of disentangling the effects of prenatal and postnatal malnutrition. Graham \& Adrianzen ( 1972 ) showed that a small group of severely-malnourished infants, who were restored to a good environment after treatment had reached the 25 th US centile-for-height by the age of approximately 7 years. Therefore a very considerable extent of 'catch-up' seems to be possible, even when the antecedent conditions have been extremely adverse. However, no information is given in this paper about the nutritional state of the mothers.

Studies in India (Iyengar, 1975) and in Guatemala (Lechtig et al. 1975) have indicated that an increase in the energy intake of poorly-nourished mothers during the later part of pregnancy produces an improvement in the birth weight of their babies. These studies give no information about the later growth of infants whose mothers' diets had been supplemented, so it is not known whether there was an 'overshoot' effect, as in the rats of group P.

If it is difficult to make comparisons between rat and man of the effects of malnutrition on physical growth, we are on even more treacherous ground in comparing mental and behavioural changes in the two species. The trend of opinion in recent years seems to be that the impairment found in malnourished children results as much from social deprivation as from an irreparable physical effect on the brain (e.g. Chavez et al. 1974; Cravioto \& DeLicardie, 1976; Richardson, 1976). Increased stimulation after physical recovery has been found to produce a pronounced improvement in developmental quotient (GranthamMcGregor \& Desai, 1975). Such findings would fit in with our conclusion that in the rat also maternal behaviour has an important effect on that of the offspring.

Perhaps all that can be said is that a better understanding of the mechanisms which programme growth has immense practical applications. The studies in the rat suggest that intervention programmes should give greater emphasis to the improvement of maternal nutrition.

The authors are indebted to Dr M. Elston for statistical analysis of the results on "learning' and discrimination obtained with the Lashley platform.

\section{REFERENCES}

Birch, H. (1972). In Nutrition, the Nervous System and Behaviour. Pan-Am. Hlth Org. Sci. Publ. no. 251 , p. 40.

Chavez, A., Martinez, C. \& Yaschine, T. (1974). In Early Malnutrition and Mental Development Swedish Nutrition Foundation Symposium no. 12, p. 21 I. Uppsala: Alunquist \& Wiksell.

Cravioto, J. \& DeLicardie, E. R. (1976). In Nutrition and Agricultural Development. [N.S. Scrimshaw \& M. Béhar, editors]. New York: Plenum Press.

Cruise, M.O. (1973). Pediatrics, Springfield 51, 620.

Dobbing, J. (1974). In Scientific Foundations of Paediatrics. [J. A. Davis \& J. Dobbing, editors]. London: William Heinemann Medical Books.

Falkner, F. (1978). In Perinatal Physiology, p. 37. [V. Stave, editor]. New York: Plenum Press. 
Frankova, S. (1974). Activitats. nerv. sup. 16, no. 2.

Graham, G. G. \& Adrianzen, T. B. (1972). Johns Hopkins Hosp. med. J. r31, 204.

Grantham-McGregor, S. M. \& Desai, P. (1975). Develop. Med. Chld Neurol. 17, 605.

Gupta, S. R. \& Christie, B. (1968). Indian J. med. Res. 56, I 14.

Heard, C. R. C. \& Stewart, R. J. C. (I97I). Hormones 2, 40.

Iyengar, L. (1975). Proc. 9th int. Congr. Nutr., Mexico 1972, vol, 2, p. 53. Basel: Karger.

Lashley, K. S. (1938). J. gen. Psychol. 18, 123.

Lechtig, A., Delgado, H., Laskey, R., Yarbrough, C., Klein, R. E., Habicht, J-P. \& Béhar, M. (I975). Am. J. Dis. Child. 129, 553.

McCance, R. A. \& Widdowson, E. M. (I962). Proc. R. Soc. B 156, 326.

Payne, P. R. \& Stewart, R. J. C. (1972). Lab. Anim. 6, 135.

Platt, B. S. \& Stewart, R. J. C. (1962). Proc. Nutr. Soc. 2r, v.

Platt, B. S. \& Stewart, R. J. C. (I967). J. Endocr. 38, 121 .

Richardson, S. A. (1976). Pediat. Res, ro, 57.

Soerjodibroto, W. S., Stewart, R. J. C. \& Heard, C. R. C. (1974). Proc. Nutr. Soc. 33, 19 A.

Stewart, R. J. C. (1970). Proc. Nutr. Soc. 29, 206.

Stewart, R. J. C. (1971). Getting the Most out of Food. p. is.

Stewart, R. J. C. (1973). Nutr. Rep. int. 7, 487.

Stewart, R. J. C. (1975a). In Nutrition and Mental Functions, p. 13. [G. Serban, editor]. New York and London: Plenum Press.

Stewart, R. J. C. (1975 b). Proc. Nutr. Soc. 34, 34A.

Stewart, R. J. C. (1976). Baroda J. Nutr. 3, 145.

Stewart, R. J. C., Preece, R. F. \& Sheppard, H. G. (1973). Proc. Nutr. Soc. 32, 103A.

Stewart, R. J. C., Preece, R. F. \& Sheppard, H. G. (I975). Br. J. Nutr. 33, 233.

Stewart, R. J. C. \& Sheppard, H. G. (I 971). Br. J. Nutr. 25, 175.

Turkewitz, G. (1975). In Nutrition and Mental Functions, p. I 13 . [G. Serban, editor]. New York and London: Plenum Press.

Waterlow, J. C. \& Rutishauser, I. H. E. (1974). In Early Malnutrition and Mental Development Swedish Nutrition Foundation Symposium no. 12, p. 13. Stockholm: Alunquist \& Wiksell. 